Available online on 15.7.2018 at http://ujpr.org
Universal Journal of Pharmaceutical Research
An International Peer Reviewed Journal
Open access to Pharmaceutical research

\title{
THE EFFECT OF HOSPITAL MANAGERS' SUCCESSION PLANNING ON ORGANIZATIONAL PERFORMANCE: A CASE STUDY OF SHOUSHTARI MATERNITY HOSPITAL IN SHIRAZ IN 2017
}

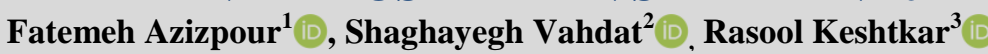

${ }^{1}$ Department of Healthcare Management, Marvdasht Branch, Islamic Azad University, Marvdasht, Iran. ${ }^{2}$ Department of Health Services Administration, SouthTehran branch, Islamic Azad University, Tehran, Iran.

${ }^{3}$ Department of Healthcare Management. Marvdasht Branch. Islamic Azad University. Marvdasht, Iran.

\section{ABSTRACT}

Objective: Widespread and rapid changes that have been created in current organizations, have led to feel lack of managers with skill for key jobs of organization and hence about the importance of succession planning in organizations be as a fundamental and vital agent should be related to strategic goals of the organization and be taken from organization's strategy and directly involves managers of line. Actually, it can be said that succession is the second important issue that current organizations are faced it. In this regard, this investigation proceeds to the investigation of the effect of hospital managers' succession planning on Shoushtari Maternity Hospital in Shiraz in 2017.

Methods: Statistical sample of the study was chosen by random method and by using Cochran formula among 240 of personnel in the hospital. Hypotheses of the study were investigated by using correlation test and regression by using SPSS software.

Results: The results in studied sample showed that succession planning has positive and meaningful effect on criteria of organizational performance (ability of employees, clarification of organizational duties, to help employees, encouragement of personnel, evaluation of personnel, increase in the credit of employees and improvement of organization's environment).

Conclusion: The results of succession planning along improving the condition of organizational environment by changing organizational environment and improving spaces and working equipment are noticed.

Keywords: Organizational performance, Shoushtari Maternity Hospital in Shiraz, Succession planning.

Article Info: Received 4 May 2018; Revised 9 June; Accepted 1 July, Available online 15 July 2018

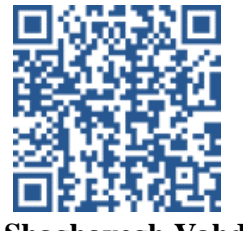

\section{Cite this article-}

Azizpour F, Vahdat S, Keshtkar R. The effect of hospital managers' succession planning on organizational performance: a case study of Shoushtari maternity hospital in Shiraz in 2017. Universal Journal of Pharmaceutical Research 2018; 3(3): 25-29.

DOI: https://doi.org/10.22270/ujpr.v3i3.162

Address for Correspondence:

Shaghayegh Vahdat, Department of Health Services Administration, SouthTehran branch, Islamic Azad University, Tehran, Iran. E-mail:sha_vahdat@yahoo.com

\section{INTRODUCTION}

Organizational performance is a general structure that refers to the condition of performing organizational operations. The most famous definition of performance has been presented by Neely and colleagues": "The process of explaining the quality related to effectiveness and competence of previous proceedings". According to this definition, the function divides into two components:

1. Competence which describes the condition of organization's use of resources in producing services or productions, it means the relation between actual and proper composition of inputs for producing certain outputs;

2. Effectiveness which is the describer of the degree related to reaching organizational goals. Evaluation of performance and more general management of performance is a process that by this, beneficial and useful information about the condition related to effective performing of affairs for reinforcing positive actions and deleting improper and unnecessary behaviors can be achieved.

Evaluating performance, in addition to preparing informational feedback, has other important performances that determining educational needs and developing human resources are of them ${ }^{2}$. Now a day, improving organizational performance has changed to one of the main troubles of organizations, in a way that unlike past, organizations search for improving organizational performance and also investigate effective factors on it to find the best solution related to growing its organization by this way. One of the 
effective factors on organizational performance can be succession plans.

The principles of succession planning from the point of view related to Peter Drucker include:

1. Managers are not born; rather they should be educated and trained.

2. In the process of training managers, the main emphasis should be on needed skills and capabilities in marketing world related to organization's future.

3. Finding talent and succession planning need regular and systematic plan.

4. Superior managers of the organization should be caretaker, promoter and main customer of these plans.

Succession planning can be used for key jobs of organization in all levels and also these plans can be effective on all important organizational aspects ${ }^{3}$. Succession planning paces toward continuance of leadership and creation of talent to enable the organization to continue its work by planned wisdom and attitude ${ }^{4}$. On this basis and also history of current researches in this field, it can be guessed that succession planning be effective on different organizational aspects including performance. So, in this research we are looking for a proper answer to this question that can succession plans have meaningful effect on organizational performance or no?

\section{Succession planning concept}

Widespread and rapid changes that have been created in current organizations, have led to feel lack of managers with skill for key jobs of organization and hence about the importance of succession planning in organizations be as a fundamental and vital agent should be related to strategic goals of the organization and be taken from organization's strategy and directly involves managers of line. Actually, it can be said that succession is the second important issue that current organizations are faced $\mathrm{it}^{5}$. About the importance of effective succession planning it can be said that succession plan can determine a guideline for human resources and existing employees, explain new human power, facilitate facing organization's changes and propose novel ways and choices in new environment ${ }^{6}$.

\section{Performance}

Nowadays, organizations are placed in permanent competition. Because of creating competition between them, organizations are looking for seizing market, customers and more sale ${ }^{7}$. Intensity of competition annually is increased and continuously all organizations for their survival and eloquence need improvement of organizational performance. Based on done investigations, a comprehensive system of human resources increases organizational performance and has fundamental role in continuous competitive advantage. Hence, through an efficient and effective management system of human resources, people can be regarded as strategic asset ${ }^{8}$.

\section{RESEARCH HYPOTHESIS}

After investigating problem of the research and fundamental studies about probable and logical answers to the questions, the following hypotheses have been collected:

Hospital managers succession planning has meaningful effect on:

1. Ability of the employees.

2. Clarity of Organizational duties.

3. Evaluation of employees.

4. Improvement of organization's environment.

\section{Literature Review}

Baladehi and Saleh in a research that was done descriptively and by survey method, proceeded to investigating succession planning and its relation with the way of leadership related to commanders and managers ${ }^{9}$. Statistical population in this research was working managers and commanders in occupational place of 17 and up to this related to police command of Mazandaran province that for choosing statistical sample according to limitation of statistical population, all-counting methods were used. Collecting data has been done by librarian information and using questionnaire. Standard questionnaire related to succession planning of Kim with 43 questions that after idea, final questionnaire according to studied society and its features (regional) 36 questions were tempered and chosen and includes three indexes of organizational factors aspect with 17 questions, personal factors with 7 questions and process aspect with 12 questions. Stability of this questionnaire was tested by Cronbach's test 0.85 . For analyzing data two methods of descriptive statistics (variables of gender, marital status, educations) and inferential statistics (correlation coefficient, regression) with SPSS software were used ${ }^{10}$. Results indicated that there is also relation between succession planning components (organizational, personal and process) and type of leadership related to commanders and managers that among them, process factors (0.467) had the highest correlation coefficient and personal factors (0.434) had the least correlation coefficient. Tsai in a study has proceeded to investigating the effect of succession planning in family businesses on organization's performance according to the role of moderating related to criteria of human resources ${ }^{11}$. Results of the study indicated that succession plans of managers have meaningful effect on organization's performance. Also, other results showed that criteria of human resources doesn't have meaningful effect on the relation between succession planning and managers performance. Minichilli and colleagues in a study proceeded to the investigation of the relation related to succession planning mechanism of managers and performance of the company ${ }^{12}$. In this research, performance of the company was assessed according to financial and nonfinancial issues and the results of the research showed that managers succession planning have meaningful relation with two financial and non-financial aspects of organizational performance. Also, they concluded that organizational environment can also have meaningful effect on the relation related to succession planning and performance of the company. Crumpucker and colleagues in an investigation as the relation of generation with succession planning stated that the main goal of their studies is the investigation of the 
relation between especial aspects of succession planning with changing generations in financial and non-financial organizations ${ }^{13}$. In this study, 12 financial companies and 28 non-financial organizations have been used as statistical society. Results of the study indicated that there is a meaningful relation between the aspects of succession planning and changing generations.

\section{METHODS}

Statistical population of the present research includes all employees and personnel of Shoushtari Maternity Hospital in Shiraz. According to this issue that the amount of statistical population estimated as 240 and also the results of Cochran formula, 169 people were chosen as final samples of the research. On the basis of goal, this investigation is practical and according to the way of collecting data is descriptive-survey and on the basis of the way of execution it can be understood as correlated. In this research for assaying investigation variables, questionnaire has been used. For collecting data related to succession planning, standard questionnaire including 43 locutions and 3 components (organizational factors, personal factors and process factors) were used. Also, for assaying organization's function, questionnaire of organizational function of Hersey and Goldsmith that has 42 locutions and 7 components was used. Originally, used practical software is other software noticeable tools related to the study, including widespread screen software of EXCELL and SPSS. Information related to theoretical catechism and literature review of librarian resources, valid sites and published articles in scientific journals and conferences was gathered.

Analyzing and testing research hypotheses investigating the condition of variables distribution by using Kolmogorov Smirnov test

Null hypothesis: Data is obeyed normal distribution.

Alternative hypothesis: Data is not obeyed normal distribution. According to Table 1, it can be said that as meaningful levels of all indexes are more than 0.05 criterion, these indexes are obeyed normal distribution.

Table 1: Investigating the condition of variables distribution.

\begin{tabular}{lccc}
\hline Variables & $\begin{array}{c}\text { The } \\
\text { amount } \\
\text { of test } \\
\text { statistic }\end{array}$ & Amount & $\begin{array}{c}\text { Meaningfulness } \\
\text { level }\end{array}$ \\
\hline $\begin{array}{l}\text { Organizational } \\
\text { performance }\end{array}$ & 0.684 & 169 & 737.0 \\
\hline $\begin{array}{l}\text { Succession } \\
\text { planning }\end{array}$ & 1.111 & 169 & 169.0 \\
\hline
\end{tabular}

\section{Investigating the relations between research} variables

1. Hospital managers succession planning has meaningful effect on:

The first hypothesis: Ability of employees.

Null hypothesis: Doesn't have on ability of employees. According to results (Table 2), the amount of correlation between two variables of succession planning and ability of employees equals to 316.0 and because the meaningfulness level of the test is less than 0.05 , so null hypothesis is not accepted and there is a meaningful relation between two studied variables. As the beta coefficient is positive, the relation between two variables is direct. Determination coefficient showed that $10 \%$ of changes related to ability of employees are explained by hospital managers succession planning. So, as observed, investigating and proceeding plans of succession planning could increase ability of employees. This issue has been occurred on the basis of increasing the motivation of employees and also increases their scientific and practical capabilities. The result of investigating this hypothesis agrees with the studies of Minichilli and colleagues and by by Tsai. 2. Hospital managers succession planning has meaningful effect on:

The Second hypothesis: Clarity of organizational duties.

Null hypothesis: Doesn't have on organizational duties. According to results (Table 3), the amount of correlation between succession planning and clarity of organizational duties equals to 337.0 and because the meaningfulness level of the 0 test is less than 0.05 , so null hypothesis is not accepted and there is a meaningful relation between two studied variables. As the beta coefficient is positive, the relation between two variables is direct. Determination coefficient showed that $05.4 \%$ of changes related to the clarity of organizational duties are explained by succession planning.

Succession planning by seeking help from beneficial courses in expressing duties and explaining job of people and condition of basic and effective performing of these obligations could improve clarity of organizational duties. This effect may be because of lack of organization paying attention to expressing the explanation of job and obligations of people during novitiate and professional courses. The result of investigating this hypothesis agrees with the studies of Minichilli and colleagues, Tsai, Beals and colleagues and Boroomand and Tavoosi.

3. Hospital managers succession planning has meaningful effect on:

The third hypothesis: Helping employees.

Null hypothesis: Doesn't have helping employees.

According to results (Table 4), the amount of correlation between two variables of succession planning and helping employees equals to 34.0 and because the meaningfulness level of the 0 test is less than 0.05 , so null hypothesis is not accepted and there is a meaningful relation between two studied variables. As the beta coefficient is positive, the relation between two variables is direct. Determination coefficient showed that $6.3 \%$ of changes related to helping employees are explained by succession planning.

Holding succession planning courses and proceedings along this issue focuses the attention of organization on employees. Paying attention to employees is acceptable for them. Working power is regarded as strategic resources of the organization that it should be tried in keeping and improving their capabilities and also distinguishing the needs of employees and deleting them. Succession planning by distinguishing weak and 
strong points of employees can revise in explaining job or organizational position of employees that is proper and acceptable for employees according to their abilities and physical features and by regarding their skills can prepare them for higher positions which all these items are considered as helping employees. The result of investigating this hypothesis agrees with the studies of Minichilli and colleagues, Tsai, Beals and colleagues and Boroom and and Tavoosi.

Table 2: Alternative hypothesis: Ability of employees.

\begin{tabular}{lccccc}
\hline Variable 1 & Variable 2 & $\begin{array}{c}\text { The amount of } \\
\text { correlation } \\
\text { coefficient }\end{array}$ & T & $\begin{array}{c}\text { Meaningfulness } \\
\text { level }\end{array}$ & $\begin{array}{c}\text { The amount of } \\
\text { determination } \\
\text { coefficient }\end{array}$ \\
\hline $\begin{array}{l}\text { Succession } \\
\text { planning }\end{array}$ & $\begin{array}{c}\text { ability of } \\
\text { employees }\end{array}$ & 316.0 & 4.548 & 0.000 & 10.0 \\
\hline
\end{tabular}

Table 3: Alternative hypothesis: Organizational duties

\begin{tabular}{cccccc}
\hline Variable 1 & Variable 2 & $\begin{array}{c}\text { The amount } \\
\text { of correlation } \\
\text { coefficient }\end{array}$ & T & $\begin{array}{c}\text { Meaningfulness } \\
\text { level }\end{array}$ & $\begin{array}{c}\text { The amount of } \\
\text { determination } \\
\text { coefficient }\end{array}$ \\
\hline $\begin{array}{c}\text { Succession } \\
\text { planning }\end{array}$ & $\begin{array}{c}\text { Clarity of } \\
\text { organizational } \\
\text { duties }\end{array}$ & 337.0 & 5.146 & 0.000 & 054.0 \\
\hline
\end{tabular}

The fifth hypothesis: evaluating employees.

Null hypothesis: Doesn't have evaluating employees. According to results (Table 5), the amount of correlation between two variables of succession planning and evaluating employees equals to 31.0 and because the meaningfulness level of the 0 test is less than 0.05 , so null hypothesis is not accepted and there is a meaningful relation between two studied variables. So, by using regression test, we proceed to investigating the condition of the relation. As the beta coefficient is positive, the relation between two variables is direct. Determination coefficient showed that $9 \%$ of changes related to evaluating employees is explained by succession planning.

In plans of succession planning for distinguishing and determining capabilities, according to these activities, some evaluations are done. Furthermore, on the basis of the announced results related to plans and courses of succession planning, some results persuade managers and especially human resources section for performing some evaluations that the results of these evaluations may lead to periodically holding evaluation in intended organization. The result of investigating this hypothesis agrees with the studies of Minichilli and colleagues, Tsai.

5. Hospital managers succession planning has meaningful effect on:

The seventh hypothesis: Improving organization's environment.

Null hypothesis: Doesn't have improving organization's environment.

According to results (Table 6), the amount of correlation between succession planning and improving organization's environment equals to 312.0 and because the meaningfulness level of the 0 test is less than 0.05 , so null hypothesis is not accepted and there is a meaningful relation between two studied variables. As the beta coefficient is positive, the relation between two variables is direct. Determination coefficient showed that $4.8 \%$ of changes related to the clarity of organizational duties are explained by succession planning. The existence of proper and favorable working conditions on the basis of working hygiene and anatomy of people are prerequisites of doing succession planning for distinguishing weak and strong points of employees and their improvements. In other words, providing lack of the existence of proper working conditions and organizational environment, working quantity and quality of people cannot be assessed and be compared with working need and distinguish are this people prepared for receiving higher working positions or no? So, proper organizational environment is one of the requisites of rule-governed succession planning and also during these courses, if professional people do not observe environment's accordance with the type of people work and investigating competency of people in environments, assess the number of faults and defects of organizational environment and report to managers. The result of investigating this hypothesis agrees with the studies of Minichilli and colleagues, Tsai.

\section{RESULTS}

On the basis of achieved results in the first hypothesis: Hospital managers succession planning has meaningful effect on the abilities of employees. So, it is suggested to:

In organization, plans of succession planning periodically and permanently are held and during these courses, educational needs of employees be distinguished until, after distinguishing weak points, it is proceeded to deleting it and enriching abilities of employees. On the basis of achieved results in the second hypothesis: Hospital managers succession planning has meaningful effect on the abilities of employees. So, it is suggested to:

People as soon as reaching to organization during novitiate courses be aware of and familiar with explaining job and also working area during novitiate professional courses in and out of organization and also during work and out of it and periodically evaluation of working power be studied to evaluate clear and proper understanding of people than these obligations. On the basis of achieved results in the third hypothesis: Hospital managers succession planning has meaningful effect on helping employees. So, it is suggested to: 
In succession planning courses, it is preceded to investigation of employee's occupational needs. Also, during succession courses, it is preceded to investigation of employee's non-occupational needs. On the basis of achieved results in the fifth hypothesis:
Hospital managers succession planning has meaningful effect on evaluating employees. So, it is suggested to: Evaluation courses of employees and managers (all personnel) are held periodically and non-periodically.

Table 4: Alternative hypothesis: Helping employees.

\begin{tabular}{cccccc}
\hline Variable 1 & Variable 2 & $\begin{array}{c}\text { The amount of } \\
\text { correlation } \\
\text { coefficient }\end{array}$ & T & $\begin{array}{c}\text { Meaningfulness } \\
\text { level }\end{array}$ & $\begin{array}{c}\text { The amount of } \\
\text { determination } \\
\text { coefficient }\end{array}$ \\
\hline $\begin{array}{c}\text { Succession } \\
\text { planning }\end{array}$ & $\begin{array}{c}\text { Helping } \\
\text { employees }\end{array}$ & 340.0 & 4.946 & 0.000 & 063.0 \\
\hline
\end{tabular}

Table 5: Alternative hypothesis: It has evaluating employees.

\begin{tabular}{cccccc}
\hline Variable 1 & Variable 2 & $\begin{array}{c}\text { The amount of } \\
\text { correlation } \\
\text { coefficient }\end{array}$ & T & $\begin{array}{c}\text { Meaningfulness } \\
\text { level }\end{array}$ & $\begin{array}{c}\text { The amount of } \\
\text { determination } \\
\text { coefficient }\end{array}$ \\
\hline $\begin{array}{c}\text { Succession } \\
\text { planning }\end{array}$ & $\begin{array}{c}\text { Evaluating } \\
\text { employees }\end{array}$ & 310.0 & 5.606 & 0.000 & 09.0 \\
\hline
\end{tabular}

Table 6: Alternative hypothesis: Improving organization's environment.

\begin{tabular}{cccccc}
\hline Variable 1 & Variable 2 & $\begin{array}{c}\text { The amount of } \\
\text { correlation } \\
\text { coefficient }\end{array}$ & T & $\begin{array}{c}\text { Meaningfulness } \\
\text { level }\end{array}$ & $\begin{array}{c}\text { The amount of } \\
\text { determination } \\
\text { coefficient }\end{array}$ \\
\hline $\begin{array}{c}\text { Succession } \\
\text { planning }\end{array}$ & $\begin{array}{c}\text { Improving } \\
\text { organization's } \\
\text { environment }\end{array}$ & 312.0 & 4.842 & 0.000 & 048.0 \\
\hline
\end{tabular}

The results of succession planning courses and periodical evaluations by using in and out organizational counselors and also by using statistical software and noble and systematic informational technologies are used. On the basis of achieved results in the seventh hypothesis: Hospital managers succession planning has meaningful effect on improving organization's environment. So, it is suggested to: The results of succession planning along improving the condition of organizational environment by changing organizational environment and improving spaces and working equipment be noticed.

\section{AUTHOR'S CONTRIBUTION}

The manuscript was carried out, written, and approved in collaboration with all authors.

\section{ACKNOWLEDGEMENTS}

The authors extend their thanks and appreciation to the Islamic Azad University, Tehran, Iran to provide necessary facilities for this work.

\section{CONFLICT OF INTEREST}

We declare that we have no conflict of interest.

\section{REFERENCES}

1. Neely AD, Adams C, Kennerley M. The Performance Prism: The Scorecard for Measuring and Managing Stakeholder Relationships. Financial Times/Prentice Hall, London, 2002.

2. Almasi, H. From evaluation of performance to management of performance, Tadbir magazine 2015; no. 56.

3. Shen W, Cannella AA. Will succession planning increase shareholder wealth? Evidence from investor reactions to relay CEO successions. Strategic Management J 2003; 24(2), 191-198. https://doi.org/10.1002/smj.2800
4.Drucker PF, Crișan C. Managementul strategic. Teora, 2001.

5.Karami M. Investigating effective factors on proper execution of succession planning in private organizations of Neyshaboor, Master thesis, Islamic Azad University, Neyshabur branch, 2011.

6. Rothwell WJ. Effective succession planning: Ensuring leadership continuity and building talent from within. AMACOM Div American Mgmt Assn, 2010.

7. Vahdat S, Hessam S, Dadashi J. The impact of hospital information system on the working process of Imam Ja'far Sadiq hospital, Alborz province-2016. Universal J Pharm Res 2018; 3(1): 7-11. https://doi.org/10.22270/ujpr.v3i1.R2

8. Gholam zadeh, D, V Jalali S. Codification of human resources strategy by using the theory of strategic reference points (Case study: Rangin Profile Kavir). Governmental management 2012; 137-152. https://doi.org/10.1016/j.sbspro.2013.04.052

9.Baladahi, M, Salehi, M. Succession planning and its relation with the style of leadership of leaders and managers, extension scientific quarterly of supervision and inspection 2016; 35:71-102.

10. Cania L. The Impact of Strategic Human Resource Management on Organizational Performance. Economia. Seria Management. 2014; 374-385

11. Tsai SF. The effect of family business succession planning maturity on organizational performance-The moderate effect of high performance human resource measures, 2015. https://doi.org/10.1108/13552559610153261

12. Minichilli A, Nordqvist M, Corbetta G, Amore MD. CEO succession mechanisms, organizational context, and performance: A socio emotional wealth perspective on family controlled firms. J Management Studies 2014; 51(7): 1153-1179. https://doi.org/10.1111/joms. 12095

13. Yazdanpanah A, Boushehri LB, Vahdat S. Comparison of the knowledge, attitude and performance of hospital managers in Bushehr province about nosocomial infections. Universal J Pharm Res 2018; 3(2): 1-5. https://doi.org/10.22270/ujpr.v3i2.128 